Urszula PĘKALA

(Kraków, PAT)

\title{
APOLOGIA CHRZEŚCIJAŃSKIEJ NAUKI O ZBAWIENIU W WIELKIEJ KATECHEZIE ŚW. GRZEGORZA Z NYSSY
}

Wielka katecheza $a^{1}$ - apologetyczno-dogmatyczne dzieło św. Grzegorza z Nyssy - powstała w 385 r. jako pomoc dla katechetów i pasterzy Kościoła w nauczaniu lub obronie wiary wobec Żydów, pogan i wyznawców różnych herezji. Zagadnienie zbawienia obejmuje jej najobszerniejszą część. Tematowi temu warto poświęcić krótką analizę, by zobaczyć, w jaki sposób pytania stawiane chrześcijanom, stają się dla Grzegorza inspiracją do refleksji teologicznej i spójnej prezentacji chrześcijańskiej doktryny, jak również ze względu na zaskakującą momentami treść odpowiedzi, jakich udziela swoim adwersarzom.

Grzegorz, pisząc o zbawieniu, posługuje się formą czasownikową oú $\zeta \omega$ lub pokrewnym mu rzeczownikiem $\sigma \omega \tau \eta{ }^{2} \alpha^{2}$. Używa również słowa oixovouía, podobnie, jak inni Ojcowie Kościoła, dla których jest to termin techniczny, oznaczający w wąskim rozumieniu życie Chrystusa od Jego narodzin aż po Mękę, Śmierć i Zmartwychwstanie, a w sensie szerokim - wszelkie interwencje Boga $w$ historii ${ }^{3}$. U Grzegorza termin oixovouia może mieć różny zakres znaczeniowy. Na podstawie kontekstu da się wywnioskować, czy odnosi się

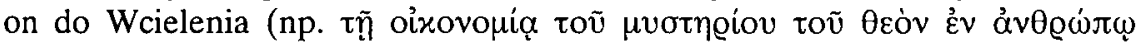

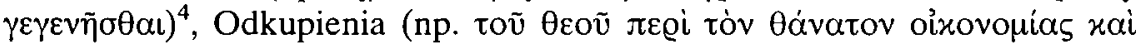

${ }^{1}$ Tekst oryginalny Wielkiej katechezy (Oratio catechetica magna) można znależć w: PG 45, 9106; GNO (W. Jaeger) III/4, ed. E. Mühlenberg, Leiden 1996, SCh 453, Paris 2000. Istnieją dwa przekłady polskie T. Sinki: św. Grzegorz z Nyssy, Wybór pism, Warszawa 1963, 57-136 (Nauka katechetyczna) i W. Kani: PSP 14, 128-183 (Wielka katecheza). Niestety sama Wielka katecheza ani omawiane $w$ niej zagadnienie zbawienia nie doczekało się na razie kompletnego opracowania w literaturze polskiej. Pewne informacje można znaleźć w podręcznikach patrologii, nielicznych artykułach oraz wstępach do zbiorów pism Nysseńczyka. W języku polskim ukazała się tylko mała część jego bogatego dorobku. Prac dotyczących samego autora jest równieź niewiele.

${ }_{2}$ Por. np. Oratio catechetica magna 8, 15, 17, 20, 23, 24, SCh 453, 202, 218, 228, 238, 256, PSP $14,146,151,154,156,160,161$.

3 Por. R. Winling, Introduction, SCh 453, 80-81.

${ }^{4}$ Por. Oratio catechetica 25, SCh 453, 258, PSP 14, 161; por. też tamże 5, 10, 24, SCh 453, 160 , 206,256, PSP $14,135,147,161$. 


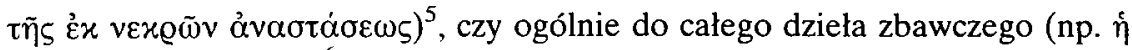
$\varkappa \alpha \theta^{\prime} \eta \dot{\eta} \mu \tilde{\varsigma} \varsigma$ oixovo $\left.\mu^{\prime} \alpha\right)^{6}$. Oprócz tego, mówiąc o Wcieleniu i Odkupieniu, Nysseńczyk posługuje się także jednoznacznymi czasownikowymi formami

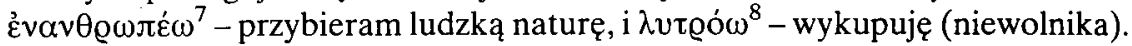

W Wielkiej katechezie napotykamy dwa rozumienia pojęcia „zbawienie”. W niektórych fragmentach Grzegorz utożsamia zbawienie $z$ samym faktem Odkupienia, czyli wyrwania człowieka z niewoli grzechu przez śmierć Chrystusa. Gdzie indziej jednak ukazuje je jako jedność Wcielenia i Odkupienia, a zatem przyjęcie przez Syna Bożego ludzkiej natury, całe Jego ziemskie życie aż do wydarzeń paschalnych włącznie: Wcielenie bowiem ukierunkowane jest na Odkupienie, a refleksja na temat Odkupienia stanowi zarazem rozważanie tajemnicy Wcielenia.

Występuje jednak u Grzegorza pewne uporządkowanie poszczególnych tematów, które upoważnia nas do tego, by w tym artykule tajemnicy Wcielenia i Odkupienia poświęcić dwa osobne punkty. Najpierw bowiem mówi on o samym fakcie Wcielenia, potem zaś o tym, w jaki sposób posłużyło ono Bogu do dokonania naszego Odkupienia.

\section{TAJEMNICA WCIELENIA}

Tajemnicę Wcielenia Nysseńczyk uważa za prawdę wiary najtrudniejszą do zaakceptowania. Czy bowiem przyjęcie ludzkiej natury nie jest niegodne Boga? Jak mogą współistnieć w Chrystusie dwie natury? Czy rzeczywiście Bóg przyszedł na ziemię? Jeśli tak, to dlaczego nie wszyscy jeszcze $w$ to wierzą? Oto odpowiedź Grzegorza.

1. Wcielenie a majestat Boga. Nieskończony, doskonały Bóg zniżył się do przyjęcia ludzkiej natury. Grzegorz podkreśla, że ten fakt nie przynosi Bogu żadnej ujmy. Jedyną hańbą jest $z^{9}{ }^{9}$, a w ludzkiej naturze stworzonej przez Boga nie ma niczego złego ${ }^{10}$ :

${ }^{5}$ Por. Oratio catechetica $16, \operatorname{SCh} 453,228$, PSP 14, 153; por. też tamże 35, SCh 453, 290, PSP $14,173$.

${ }^{6}$ Por. Oratio catechetica $24, \mathrm{SCh} 453,240$, PSP 14,161 ; por. też tamże 20 i 26 , SCh 453,256 i 258, PSP 14, 157 i 162.

7 Por. Oratio catechetica 26, SCh 453, 264, PSP 14, 163.

${ }^{8}$ Por. Oratio catechetica 23, SCh 453, 252, PSP 14, 159.

9 Por. Oratio catechetica 9, SCh 453, 204, PSP 14, 146; tamże 27, SCh 453, 268, PSP 14, 164.

${ }^{10}$ Por. Basilius Caesarensis, Epistola 161, 3, PG 32, 972, thum. W. Krzyżaniak: Sw. Bazyli Wielki, Listy, Warszawa 1972, 324-325. Grzegorz różni się tu w poglądach od Orygenesa, który nie uważając materii za złą, dostrzega w niej jednak jakiś związek z grzechem, por. M. Michalski, Antologia literatury patrystycznej, I, Warszawa 1982, 339. 
„Bóg jest prawdziwą cnotą, a przeciwieństwo cnoty leży tylko w grzechu, nie w naturze, a Bóg rodzi się nie $w$ grzechu, lecz $w$ naturze człowieka i złym jest tylko stan grzechu, w którym Bóg jednak nigdy nie był i z natury być nie może"11.

Natura ludzka sama w sobie nie ma nic wspólnego $z$ grzechem, więc jej przyjęcie w żaden sposób nie jest niegodne Boga. Kto twierdzi inaczej, ten dochodzi do absurdalnego wniosku, iż nie przystoi Bogu to, co jest dobre ${ }^{12}$. $\mathrm{Na}$ podstawie rozumowania Grzegorza wypadałoby tu sformułować jeszcze jeden argument, którego on sam wprost nie podaje: gdyby natura człowieka była zła, Wcielenie nie byłoby w ogóle możliwe, bo Bóg „z natury” nie może być w stanie grzechu.

Pojawia się jednak kolejny problem. Człowiek jest zbyt niskim stworzeniem wobec Bożego majestatu, by Bóg mógł stać się człowiekiem. Może więc zjednoczenie $z$ ludzką naturą i tak uwłacza Stwórcy, nawet jeśli nie jest ona sama w sobie zła? Odpierając ten zarzut, Grzegorz thumaczy, że Bóg jest równie wzniosły i niedostępny wobec każdego stworzenia - tak ziemskiego, jak i niebieskiego.

„Prawdziwa nauka nie dopuszcza wobec nieskończonego Majestatu żadnego porównania $\mathrm{z}$ wyższymi i niższymi stworzeniami. Bo wszystkie są jednakowo dalekie pod Bożą wszechmocą, tak że jeśli ziemską naturę uważać będziemy za niegodną polączenia z Bogiem, nie znajdziemy innej od niej godniejszej"13.

Poza tym Bóg przyjąl naturę człowieka, bo to człowiek potrzebował uleczenia. Dlatego Bóg nie mógł stać się jakąś inną „istotą niebieską", ale stał się właśnie czlowiekiem. „Nie wyzdrowieje przecież chory, jeśli lekarstwo przyjmuje nie ta

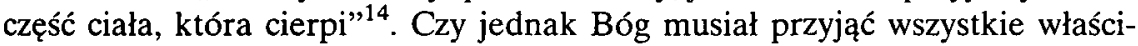
wości ludzkiej natury - od narodzin, poprzez wzrost, odżywianie się, aż po śmierć? Nysseńczyk odpowiada:

„[...] gdy ludzkie życie na początku, przy końcu i w środku splamiły grzechy, oczyszczająca moc Boża musiała rozciągać się na wszystko, a nie mogła jedną część uzdrowić, drugą zaś zostawić chorą"15.

Bóg, stając się człowiekiem, zniża się do zjednoczenia ze stworzoną naturą. Gdzie zatem przejawia się we Wcieleniu moc Boga? Przecież za przejaw Bożej mocy uznaje się raczej sprawianie wielkich dziel, takich jak choćby stworzenie świata, czy kierowanie nim. Grzegorz tłumaczy, że działać zgodnie z własną naturą nie jest niczym nadzwyczajnym. Czynienie przez Boga tego, co przekra-

11 Oratio catechetica $15, \mathrm{SCh} 453,220$, PSP $14,151$.

12 Por. Oratio catechetica 9, SCh 453, 204, PSP 14, 147.

13 Oratio catechetica 27, SCh 453, 270, PSP 14, 165.

14 Oratio catechetica 27, SCh 453, 268, PSP 14, 164.

15 Oratio catechetica 27, SCh 453, 266, PSP 14, 163. 
cza możliwości stworzeń, jest właściwe Bożej mocy. Dziwne byłoby raczej, gdyby Bóg nie czynił swych wielkich dzieł. W tym, „że Bóg zstąpił na niziny człowieczeństwa, uwydatniła się Jego potęga o wiele bardziej niż w przewyższających przyrodzone siły cudach"16. We Wcieleniu objawia się „nadmiar mocy", bo:

„wzniosłość schyla się ku niskości i w niskości daje się widzieć, choć sama się nie zmniejsza. Boskość łączy się z naturą ludzką i nią się staje, choć nie przestaje być sobą"17.

Bóg swym działaniem lamie nasze schematy myślenia o Nim. Działa niejako wbrew swej naturze, a mimo to pozostaje ona nienaruszona - $\mathrm{i}$ to jest największy cud.

2. Dwie natury w Chrystusie. W Chrystusie „Boskość łączy się z ludzkością”

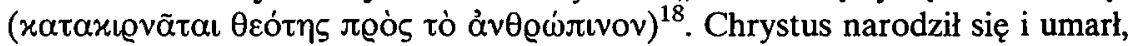
jak człowiek, ale zarówno w Jego narodzeniu, jak i w śmierci było coś, co przekracza właściwości ludzkiej natury. Narodził się bowiem z dziewicy ( $\dot{\varepsilon} x$ $\pi \alpha \varrho \theta \varepsilon v i \alpha \varsigma)^{19}$, a po śmierci zmartwychwstaf ${ }^{20}$. Potwierdzeniem boskiej natury Chrystusa są Jego cuda czynione podczas ziemskiej działalności ${ }^{21}$ oraz znaki dokonywane już po zmartwychwstaniu ${ }^{22}$. Wszystko to zostało opisane w Piśmie świętym i dowodzi niepodważalnie bóstwa Chrystusa ${ }^{23}$. Grzegorz pisze:

"[...] wszystkie przekazane nam przez Ewangelię słowa i czyny są zgodne $\mathbf{z}$ Boskim życiem, i nie ma tam niczego, co by prócz ludzkich rysów nie nosiło również charakteru boskiego, [...] mądrość każe [...] w tym, co nieśmiertelne dostrzegać człowieczeństwo, a w tym, co ludzkie, szukać usilnie Boskości"24.

Nauka o dwóch naturach w Chrystusie rodzi w przeciwnikach pytanie: ,jak to, co jest nieskończenie małe [tj. ciało ludzkie], potrafi objął nieskończoną wielkość"? ${ }^{25}$. Grzegorz stwierdza, że pytanie jest błędnie postawione, ponieważ chrześcijanie nie twierdzą, jakoby ciało obejmowało naturę Bożą. Jest ono $\mathrm{z}$ nią połączone na podobnej zasadzie, jak ciało i dusza w człowieku. Dusza ma

${ }^{16}$ Oratio catechetica $24, \mathrm{SCh} 453,252$, PSP $14,160$.

17 Oratio catechetica 24, SCh 453, 254, PSP 14, 160.

${ }_{18}$ Oratio catechetica 11, SCh 453, 208, PSP 14, 148.

19 Por. Oratio catechetica 13, SCh 453, 214, PSP 14, 150. Dosłownie: „z dziewictwa”, jednak R. Winling thumaczy „d'une vierge”, a W. Kania „z Panny”. Warto zaznaczye, że jest to jedyne miejsce w całej Wielkiej katechezie, gdzie Grzegorz nawiązuje do osoby Maryi.

20 Por. Oratio catechetica 13 , SCh 435, 214, PSP 14, 149-150.

21 Por. Oratio catechetica 23, SCh 453, 248-250, PSP 14, 159.

22 Por. Oratio catechetica 32, SCh 453, 292, PSP 14, 170.

${ }^{23}$ Por. Oratio catechetica 12 , SCh 453, 212, PSP 14, 149.

24 Oratio catechetica 32, SCh 453, 286-288, PSP 14, 169.

25 Oratio catechetica 10, SCh 453, 204, PSP 14, 147. 
naturę duchową i nie podlega żadnemu ograniczeniu przez ciało. A skoro „dusza ludzka, mimo swego $\mathrm{z}$ natury połączenia $\mathrm{z}$ ciałem, może wszędzie przebywać, cóż nas zmusza mówić, iż naturę Bożą ogranicza ciało" ${ }^{26}$. Nysseńczyk posługuje się tu przykładem płonącej lampy i płomienia. Płomień jest czym innym niż sama lampa, a jednak nie da się ich rozłączyć. Jak płomień nie jest zamknięty przez materiał lampy, tak człowieczeństwo nie zamyka bóstwa ${ }^{27}$.

A w jaki sposób dwie natury łączą się ze sobą? Grzegorz posługuje się tu tą samą analogią do połączenia ciała i duszy w człowieku. Przyznaje, że jest to tajemnica. Jeśli zaś w człowieku jest coś niepojętego, to o ileż bardziej w Bogu:

„[...] nie zdołamy pojąć sposobu zjednoczenia Boskości z człowieczeństwem. Nie wątpimy jednak w narodzenie Boga w ludzkiej naturze [...], lecz jak to się stało, nie możemy powiedzieć, bo to przewyższa nasz rozum"28.

3. Dowody przyjścia Boga na ziemię. Czy rzeczywiście Bóg przyszedł na ziemię? Na dowód Wcielenia - obok cudów opisanych w Ewangeliach - Grzegorz przywołuje także świadectwo faktów ${ }^{29}$. Przyjście Chrystusa wywarło wpływ zarówno na życie pogan, jak Żydów. Świat pogański ogarnięty był bałwochwalstwem. Składano bogom krwawe ofiary, budowano im ołtarze i świątynie, uprawiano wróżbiarstwo:

„Lecz gdy się objawiła [...] laska Zbawiciela Boga wszystkim ludziom, która przybyła do nas w naturze ludzkiej, natychmiast wszystko jak dym się rozwiało [...]. Na miejscu pogańskiego kultu na całym świecie powstały ku czci Chrystusa świątynie i ołtarze, wprowadzono świętą i bezkrwawą ofiarę"30.

Nysseńczyk nawiązuje tu prawdopodobnie do wydarzeń, jakie nastąpiły po ogłoszeniu edyktu Teodozjusza z 380 r., który zniósł kult pogański, a z chrześcijaństwa uczynił religię państwową. Podobnie, jak w przypadku pogańskiego bałwochwalstwa, upadł też żydowski kult, sprawowany w świątyni Jerozolimskiej:

„Ze świątyni [zostały] tylko ślady, ze wspaniałego miasta gruzy i nie ma już nic $\mathrm{z}$ narodowych pamiątek Żydów, nawet miejsce czci Bożej w Jerozolimie z rozkazu panujących stało się dla nich niedostępne"31.

Grzegorz ma przypuszczalnie na myśli zburzenie świątyni w 70 r. lub wybudowanie w miejscu Jerozolimy - po stłumieniu żydowskiego powstania - rzymskiego miasta Aelia Capitolina w 134 roku.

\footnotetext{
${ }^{26}$ Oratio catechetica 10, SCh 453, 204, PSP 14, 147.

27 Por. Oratio catechetica 10, SCh 453, 204, PSP 14, 147.

${ }^{28}$ Oratio catechetica 11, SCh 453, 208, PSP 14, 148.

29 Por. Oratio catechetica 18, SCh 453, 230, PSP 14, 154

${ }^{30}$ Oratio catechetica 18, SCh 453 232, PSP 14, 155.

${ }^{31}$ Oratio catechetica 18, SCh 453, 234, PSP 14, 155.
} 
Kolejnym argumentem za przyjściem Boga na ziemię jest dla Nysseńczyka świadectwo życia chrześcijan, które stało się wyrazem prawdziwej „miłości

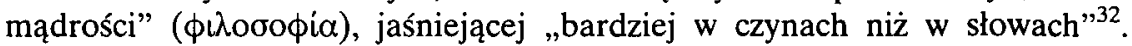
Wspomina on czasy prześladowań, kiedy chrześcijanie $\mathrm{z}$ odwagą ponosili śmierć za wiarę, „do czego nie byliby zdolni bez niewątpliwego dowodu przyjścia Boga na ziemię"33.

Część wspomnianych tu wydarzeń dotyka w jakiś sposób samego Grzegorza. Jego rodzina doświadczyła prześladowań - dziadek zginął jako męczennik, a on sam przeżył niezasłużone wygnanie ze strony proariańskiego synodu. Musial być świadkiem zmian zachodzących po edykcie Teodozjusza z 380 roku. Wielka katecheza powstała w 385 r., czyli zaledwie pięć lat później. Prawdopodobnie znał Teodozjusza osobiście - był przyjacielem dworu cesarskiego.

4. Powołanie do wiary. Skoro Bóg przyszedł na ziemię i skoro można wskazać na to dowody, to dlaczego tak niewielu wierzy w Jego przyjście? Może Bóg nie chciał, a może nie mógł udzielić wszystkim łaski wiary? Według Nysseńczyka obie możliwości są niegodne Boga. Łaska wiary nie jest dla wybranych, ale „powołanie do wiary dotyczy wszystkich, bez względu na wiek i godność czy narodowość, jednakowo" ${ }^{34}$. Bóg rozesłal głosicieli swego słowa po całym świecie, by wiara mogła dotrzeć do każdego. Człowiek dzięki wolnej woli może ją przyjąć lub odrzucić, a Bóg szanuje jego decyzję:

„Słuszniej by więc było skierować zarzut do tych, co nie doszli do wiary, niż do Tego, który wezwał do wiary [...]. Skoro bowiem laska wszystkim była dana, gdy jej kto nie przyjął, nie mógł ganić kogo innego"35.

Bóg nie jest winien temu, że człowiek nie wierzy.

Czy jednak Bóg nie mógł zmusić opornych do przyjęcia tego dobrodziejstwa, jakim jest wiara? Grzegorz odpowiada stanowczo, że nie. Przymus oznaczałby dla czlowieka utratę wolnej woli. Bez wolnej woli nie ma wolności myślenia, bo za człowieka decyduje ktoś inny. Zostaje on zdeterminowany do podejmowania określonych działań. Bóg, jako dobry, nie mógł doprowadzić do takiej sytuacji i pozostawil człowiekowi wolność wyboru. Dlatego powtarza Grzegorz - nie można winić za ludzką niewiarę Boga, ale tych, co $\mathrm{z}$ własnej woli wiary nie przyjęli ${ }^{36}$.

32 Oratio catechetica 18, SCh 453,232 , PSP $14,155$.

33 Oratio catechetica 18, SCh 453, 234, PSP 14, 155.

${ }^{34}$ Oratio catechetica 30 , SCh 453, 278, PSP 14, 167.

${ }^{35}$ Oratio catechetica 30 , SCh 453, 280, PSP 14, 167-168.

${ }^{36}$ Por. Oratio catechetica 31, SCh 453, 280-282, PSP 14, 168; zob. M.B. von Stritzky, Zum Problem der Erkenntnis bei Gregor von Nyssa, Münster 1973, 54. 


\section{DZIEŁO ODKUPIENIA}

Po krótkiej analizie nauki Grzegorza, dotyczącej bezpośrednio samego faktu przyjścia Boga na ziemię, przejdźmy do jego wykładu o sposobie, w jaki Bóg odkupił człowieka. Jest to szczytowy moment Bożego zaangażowania się w ludzki los. Przeciwnicy stawiają pytanie: dlaczego Bóg wybrał „drogę okrężną" - czyli krzyż i śmierć swojego Syna? Czy nie mógł zbawić człowieka samym aktem woli? ${ }^{37}$. „Na takie słowa ludziom rozsądnym wystarczy powiedzieć, że i lekarzowi nie przepisują chorzy sposobu leczenia"38 - odpowiada Nysseńczyk. Ale to nie jest jego jedyna odpowiedź.

1. Sposób odkupienia czlowieka. Tłumacząc, dlaczego Bóg odkupił człowieka przez Wcielenie i śmierć swego Syna, Grzegorz posługuje się rozważaniem przymiotów Bożych, ujawniających się w Jego działaniu. Wychodzi z założenia, że skoro Bóg jest absolutnie doskonały, to wszystkie Jego przymioty trzeba brać pod uwagę razem, nie odrywając żadnego $\mathrm{z}$ nich od pozostałych. Jako przymioty szczególnie widoczne w dziele Odkupienia wymienia

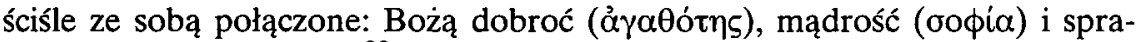

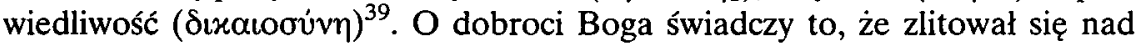
upadłym człowiekiem i postanowił go zbawić. Mądrość przejawia się w tym, że wie On, co należy czynić dla zbawienia człowieka i osądza, co jest prawdziwie dobre ${ }^{40}$.

A gdzie w dziele Odkupienia dostrzegamy Bożą sprawiedliwość? Człowiek wybrał zło $z$ własnej woli i znalazł się w niewoli szatana ${ }^{41}$. Grzegorz porównuje ten stan do sytuacji ludzi, którzy sami zaprzedali się komuś w niewolę. Każda próba wyzwolenia ich siłą, nawet powodowana wspólczuciem, byłaby bezprawiem, ponieważ ich nabywca dokonał transakcji zgodnie $\mathrm{z}$ prawem ${ }^{42}$. Gdy więc Bóg postanowił wydobyć człowieka z niewoli szatana, ,nie mógł uczynić tego przemocą, lecz w sposób sprawiedliwy. A polega on na tym, by właścicielowi dać taki okup, jaki ten zażąda za trzymanego u siebie więźnia"43.

Bóg przewidział, że szatan w swej pysze uwolni człowieka tylko w zamian kogoś, kto przedstawia większą niż czlowiek wartość. Kiedy więc szatan zobaczył u Jezusa nadludzką moc objawiającą się w cudach, Jego wybrał na okup,

\footnotetext{
${ }^{37}$ Por. Oratio catechetica $15, \mathrm{SCh} 453,218$, PSP $14,151$.

38 Oratio catechetica 17, SCh 453, 230, PSP 14, 154.

39 Oratio catechetica 20, SCh 453, 238, PSP 14, 156-157; tamże 21, SCh 453, 238, PSP 14, 157.

40 Por. Oratio catechetica 20-23, SCh 453, 236-252, PSP 14, 156-160.

${ }^{41}$ Grzegorz stosuje różne określenia szatana, najczęściej évavtíos - przeciwnik (np. Oratio

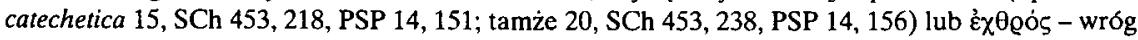
(np. Oratio catechetica 21, SCh 453, 244, PSP 14, 158; tamże 23, SCh 453, 250, PSP 14, 159).

42 Por. Oratio catechetica 22, SCh 453, 244-246, PSP 14, 158.

43 Oratio catechetica 22, SCh 453, 246, PSP 14, 158.
} 
widząc, że na tej zamianie zyska więcej niż posiada ${ }^{44} . \mathrm{Z}$ takiego rozumowania można by wysnuć - niekoniecznie zamierzony przez Grzegorza - wniosek, że Chrystus ofiarował się za nasze grzechy szatanowi, a nie Bogu Ojcu:

„Dla stania się dostępnym żądającemu za nas okupu ukryło się Bóstwo w osłonie naszej natury, by ten, jak lapczywe ryby, wraz z przynętą ciała mógł połknąć również haczyk Bóstwa",45.

W ten sposób Bóg wprowadził życie tam, gdzie panowała śmierć, i pokonał moce szatana. Według Grzegorza w tym właśnie objawiła się sprawiedliwość Boga polączona $\mathrm{z}$ mądrością. Jako sprawiedliwy, Bóg wyzwolił człowieka drogą zamiany, zamiast wydrzeć go szatanowi przemocą. Jako mądry, znalazł sposób, by stać się dostępnym dla wroga, dzięki czemu owa zamiana mogła dojść do skutku.

Analizując przytoczone tu rozumowanie Grzegorza odnosi się wrażenie, że cała tajemnica Wcielenia została sprowadzona do jakiejś teorii spisku - jakby Bóg przyjął ludzkie ciało na podstawie czystej kalkulacji i przewidywania tego, co zrobi szatan - nawet jeśli Bóg przeprowadził całe to działanie, bo jest dobry i lituje się nad nędzą człowieka. Rodzi się pytanie, czy szatan nie został w takim ujęciu potraktowany jako partner w pewnej transakcji, a nie jako stworzenie nieskończenie niższe od Boga. A może tu też chodziło Grzegorzowi o podkreślenie szacunku Boga dla wolności woli rozumnych stworzeń? Nysseńczyk przewidując zarzut, że Bóg postąpił z szatanem nieuczciwie, podkreśla jeszcze raz Bożą sprawiedliwość i mądrość, ujmując je w innym aspekcie:

„Cechą sprawiedliwego jest oddać każdemu, co się mu należy, mądrego zaś nie uchybić sprawiedliwości i zamierzonych uczynków miłości nie odłączać od sprawiedliwości, lecz zręcznie łączyć jedno z drugim, zarówno oddając każdemu, co się mu należy, jak i pozostając wiernym zamierzonemu dobru" ${ }^{46}$.

Szatan oszukał człowieka, więc - według sprawiedliwości - sam zostal oszukany. Oszustwo popełnione przez niego było niesprawiedliwe, zaś oszustwo, jakiego dopuścił się Bóg, sprawiedliwe. Można zarzucić Grzegorzowi, że tak ujęte postępowanie Boga jest bliższe zasadzie „oko za oko, ząb za ząb”, niz sprawiedliwości.

Dalej Nysseńczyk pogrąża swoją argumentację jeszcze bardziej. Pisze, że o sprawiedliwości i niesprawiedliwości decyduje cel postępowania:

44 Por. Oratio catechetica 23, SCh 453, 250, PSP 14, 159. Podobna teorię na temat okupu zlożonego szatanowi w zamian za czlowieka przedstawia Bazyli Wielki, por. J.N.D. Kelly, Począki doktryny chrześcijańskiej, tłum. J. Mrukowna, Warszawa 1988, 285.

${ }^{45}$ Oratio catechetica 24, SCh 453, 254, PSP 14, 160; por. też tamże 23, SCh 453, 250, PSP 14, 159.

${ }^{46}$ Oratio catechetica 26, SCh 453, 260, PSP 14, 162. 
„Celem, jaki tu Bóg zamierzył, było dobro. Szatan bowiem posłużył się oszustwem dla zguby ludzkości, Bóg zaś użył dobrze przemyślanego podstępu dla zbawienia człowieka, wyświadczając dobrodziejstwo nie tylko temu, co upadł, lecz i sprawcy naszej zguby" ${ }^{\text {. }}$.

Tym tekstem Grzegorz dowodzi - trudno stwierdzić, na ile świadomie - że „cel uświęca środki”. Dzięki Bożemu podstępowi także „winowajca” zostaje „ule-

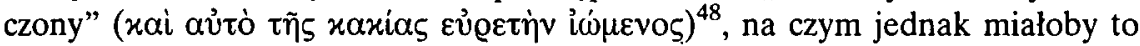
polegać, Nysseńczyk nie wyjaśnia. Spotykamy tu nawiązanie do teorii apokatastazy, zgodnie z którą Bóg w swym zamyśle miałby doprowadzić całe stworzenie nie wylączając upadłych duchów - do pierwotnej szczęśliwości i piękna ${ }^{49}$.

Powróćmy do postawionego wcześniej problemu: dlaczego Bóg nie zbawił człowieka samym aktem woli? Bo sprawiedliwym było wykupić człowieka, a nie odebrać go szatanowi przemocą. Dzieła świadczą o naturze tego, kto je wykonuje. Bóg dobry, mądry i sprawiedliwy okazał te przymioty w dziele zbawienia, a to znaczy, że droga, którą obrał, była słuszna. Cały wywód słuzą̧cy za odpowiedź na powyższe pytanie jest dość zagmatwany i mało przejrzysty. Grzegorz chce za wszelką cenę ocalić prawdę, że postępowanie Boga akurat w taki sposób jest uzasadnione. Wskutek tego sposób działania Boga jawi się jako logiczny, ale czy nie staje się niemoralny? Nysseńczyk - nie wiadomo dlaczego - jakby zapomniał w tym miejscu wyeksponować tak istotny motyw, jakim była miłość, dla której Bóg stał się człowiekiem. Wspomina on o tym przecież wcześniej - również w kontekście Wcielenia:

„Jeśli więc właściwym znakiem natury Boskiej jest milość ku ludziom ( $\phi i \lambda a v-$ $\theta \varrho \omega \pi i \alpha$, masz tym samym przyczynę, o którą pytałeś, masz powód przyjścia Boga do ludzi"so.

2. Śmieré krzyżowa Chrystusa. Czy Chrystus musiał umrzeć? Częściową odpowiedź na to pytanie znajdujemy już wcześniej, gdy Grzegorz mówi o tym, że Bóg musiał przyjąć wszystkie właściwości naszej natury, łącznie ze

${ }^{47}$ Oratio catechetica 26, SCh 453,262 , PSP $14,162-163$.

48 Oratio catechetica 26, SCh 453, 262, PSP 14, 163.

49 Por. Kelly, dz. cyt., s. 257; Michalski, dz. cyt., II, s. 266. W Wielkiej katechezie Grzegorz jest dosyć kategoryczny w swych stwierdzeniach o „uleczeniu” szatana. Odnosi się wrażenie, że zbawienie szatana dokonuje się w sposób dość arbitralny, niezależny od jego woli. Z pisma pt. Diälog $z$ siostrq Makrynq o duszy $i$ zmartwychwstaniu wynika jednak, że Grzegorz traktuje raczej teorię apokatastazy jako pewną nadzieję (hipotezę) co do ostatecznego kształtu stworzenia - podobnie jak Orygenes, por. H. Pietras, Poczq̨tki teologii Kosciola, Kraków 2000, 323-324. Wyraża przy tym pogląd (De anima et resurrectione [Macrinia], PG 46, 72, PSP 14, 51), że „kiedys, gdy po długich wiekach wszelkie zło zostanie zmazane, żadne stworzenie nie znajdzie się poza zasięgiem dobra, lecz panowanie Chrystusa zostanie przyjęte również przez wymienione na końcu [złe] duchy", uwzględniając niejako akt ich własnej woli w ponownym zwróceniu się ku Bogu.

${ }^{50}$ Oratio catechetica 14, SCh 453, 216, PSP 14, 150. 
śmiertelnością, by uleczyć ludzkie życie skażone grzechem w całej jego rozciągłości ${ }^{51}$. Teraz odpowiedź ta zostaje dopełniona:

„Kto raz ma udział w człowieczeństwie, ten musi przyjąć wszystkie jego wlaściwości [...]. Ponieważ winien był nastąpić powrót całej naszej natury ze śmierci, [Bóg] chciał [...] tak bardzo do śmierci się zbliżyć, aby dotknąć śmiertelności i wlasnym ciałem dać początek zmartwychwstaniu, wskrzeszając człowieka swą mocą"52.

Jak to się dzieje, że zmartwychwstanie przechodzi z Chrystusa na każdego czlowieka? Grzegorz wyjaśnia: rodzaj ludzki jest jakby „jedną osobą”; jeśli jakieś doznanie staje się udziałem jego części, musi się rozciągać na całośćc ${ }^{53}$. Ciało Chrystusa było złożone $\mathrm{z}$ tej samej materii, co ciało każdego człowieka, więc należy On do tej jedności, jaką stanowi cała ludzkośćc ${ }^{54}$.

Czy jednak Chrystus musiał umrzeć na krzyżu? Tak. Krzyż bowiem nie jest tylko narzędziem haniebnej śmierci, ale ma głębokie znaczenie teologiczne jego kształt przypomina nam, że w każdym rodzaju stworzeń możemy dostrzec utrzymującą je w istnieniu Bożą naturę. Nysseńczyk pisze:

„Właściwością Boskości jest przenikanie wszystkiego i rozciąganie się na wszystko, co istnieje, na calą naturę bytu i na każdą jego część, bo nie wytrwałoby coś $\mathrm{w}$ istnieniu, gdyby nie trwało $w$ czymś istniejącym. Tym zaś, co istnieje właściwie i pierwotnie, jest boska natura. Do niewątpliwej wiary, że musi się ona znajdować we wszystkim, co istnieje, zmusza nas trwałość tego, co istnieje. Uczy nas o tym krzyż"s5.

Grzegorz powohuje się w swej interpretacji na fragment Listu do Efezjan $(3,18)$ : belki krzyża rozchodzące się ze środka w czterech kierunkach wskazują na różne byty stworzone. Ukrzyżowany Chrystus w swej boskiej naturze lączy je wszystkie w jedną całośćs ${ }^{56}$.

\section{$* * *$}

Śledząc tok rozumowania Grzegorza, odpowiadającego na zarzuty różnych przeciwników, możemy zauważyć, że jego argumentacja jest bardzo „nierówna". Uzasadnienia zawsze aktualne mieszają się z całkowicie chybionymi. Nie

${ }^{51}$ Por. Oratio catechetica 27, SCh 453, 266, PSP 14, 163-164.

52 Oratio catechetica 32, SCh 453, 284, PSP 14, 168-169.

${ }^{53}$ Grzegorz przekłada tu biblijną ideę $\mathrm{z}$ Listu do Rzymian na schemat zaczerpnięty z platonizmu, por. Kelly, dz. cyt., s. 284.

54 Por. Oratio catechetica 32, SCh 453, 286, PSP 14, 169.

55 Oratio catechetica 32, SCh 453, 288, PSP 14, 169; por. także De professione christiana 27, GNO VIII 1, 139, tłum. J. Naumowicz: Co znaczy być chrześcijaninem?, w: Św. Grzegorz z Nyssy, O naśladowaniu Boga. Pisma ascetyczne, Kraków 2001, 51-52: „Nic nie może istnieć, jeśli byłoby oddzielone od Tego, który jest. Natura boska w równym stopniu związana jest $z$ każdym $\mathrm{z}$ bytów i dzięki swej ogarniającej mocy obejmuje wszystko w sobie".

${ }^{56}$ Por. Oratio catechetica 32, SCh 453, 288-292, PSP 14, 169-170. 
do przyjęcia jest rozumowanie dotyczące sposobu, jakim Bóg posłużył się, by odkupić człowieka. Nysseńczyk bowiem w pewnej mierze sprowadził dzieło Odkupienia do teorii spisku, w której Bóg pozornie zawiera układ z szatanem, a w rzeczywistości ma zamiar go oszukać. Tak bardzo chciał wykazał zasadność zbawienia człowieka przez Wcielenie i śmierć Bożego Syna, że doszedł do wniosków rażąco niezgodnych z chrześcijańską moralnością, choć - trzeba przyznać - spójnych logicznie.

Wiele jednak spośród wyjaśnień Grzegorza zachowuje wartość do dziś. Dowodzi on rzeczywistego objawienia się Boga w ludzkim ciele, tłumacząc jednocześnie, iż przyjęcie naszej natury nie przynosi Mu wstydu, bo natura ta jest dobra. Wykazuje, jak Bóg przez Wcielenie uzdrawia całe ludzkie życie zranione przez grzech. Podkreśla prawdę o wolności ludzkiej woli, którą szanuje sam Bóg. Nawet śmierć Chrystusa przez ukrzyżowanie - uważana za haniebną - ma swe głębokie uzasadnienie i sens.

Grzegorz nie unika pytań - nawet trudnych, nawet tych, które, jak by się wydawało, są atakiem na podstawy doktryny chrześcijańskiej. Stają się one dla niego inspiracją do twórczego jej przeanalizowania. Z odpowiedniego uporządkowania pytań i odpowiedzi powstaje spójna teologiczna wizja tajemnicy Wcielenia i Odkupienia. Lektura Wielkiej katechezy uświadamia, że spotkanie $\mathrm{z}$ niewierzącymi lub błądzącymi nie musi stanowić zagrożenia dla naszej wiary, ale może prowadzić obie strony do pełniejszego odkrycia prawdy. Chrześcijanin, który głosi Ewangelię lub jej broni, nigdy nie jest tylko dającym; on także otrzymuje - ma bowiem szansę dojść do głębszego i pełniejszego rozumienia tego, w co sam wierzy.

\section{APOLOGIE DER CHRISTLICHEN LEHRE ÜBER DAS HEILSGESCHEHEN IN ORATIO CATECHETICA MAGNA DES HL. GREGOR VON NYSSA}

\section{(Zusammenfassung)}

Die Große katechetische Rede des hl. Gregors von Nyssa wurde im 4. Jahrhundert als ein Handbuch für christliche Katecheten geschrieben. Das ist vor allem eine Apologie der christlichen Lehre über das Heilsgeschehen. Gregor zählt hier viele Fragen auf, die von Juden, Heiden und Häretiker gestellt werden - vor allem: Warum ist Gott Mensch geworden? Ist das überhaupt wahr und möglich? Warum musste Christus sterben, um uns zu erlösen? Aus den Antworten auf gestellte Fragen schafft Gregor eine kurze, aber komplette Auslegung des Glaubens. Argumente, die er formuliert, sind zum großen Teil aktuell bis heute. Es gibt aber auch solche, mit denen man keinesfalls einverstanden sein kann. In diesem Artikel wurden alle Vorwürfe und Gregors Antworte zusammengestellt und kritisch betrachtet. 